\title{
EKSPLORASI ETNOMATEMATIKA PADA BATIK GAJAH MADA MOTIF SEKAR JAGAD TULUNGAGUNG
}

\author{
Ethnomathematics Exploration in Batik Gajah Mada's Sekar Jagad \\ Tulungagung
}

\author{
Dian Septi Nur Afifah ${ }^{*}$, Ika Mariana Putri ${ }^{2}$, Tomi Listiawan ${ }^{3}$ \\ 1,2,3 STKIP PGRI Tulungagung (Prodi Pendidikan Matematika, STKIP PGRI Tulungagung) \\ Jl. Mayor Sujadi Timur, No. 7, Tulungagung, 66221, Indonesia \\ e-mail: 1*dian.septi@stkippgritulungagung.ac.id ;² ikamarianaputri@gmail.com ; \\ ${ }^{3}$ tomi@stkippgritulungagung.ac.id
}

Corresponding author*

\begin{abstract}
Abstrak
Etnomatematika merupakan matematika yang terdapat dalam budaya. Tujuan dari penelitian ini untuk mengeksplorasi konsep-konsep matematika pada Batik Gajah Mada Motif Sekar Jagad Tulungagung. Metode penelitian yang digunakan adalah matode kualitatif dengan pendekatan etnografi. Adapun teknik pengumpulan data yang digunakan yaitu studi pustaka, wawancara dan dokumentasi. Teknik analisis data yang digunakan yaitu reduksi data, penyajian data, kesimpulan. Pengecekan keabsahan data dilakukan dengan perpanjangan pengamatan, meningkatkan ketekunan, menggunakan bahan referensi, mengadakan member check. Hasil dari penelitian ini adalah pada Batik Gajah Mada motif Sekar Jagad Tulungagung terdapat konsep matematika berupa bangun datar, geometri transformasi, sudut dan garis. Adapun bangun datar yang terdapat pada batik ini yaitu jajar genjang, elips dan belah ketupat. Geometri transformasi yang terdapat pada batik ini yaitu pencerminan. Sedangkan sudut dan garis yang terdapat pada batik ini yaitu sudut tumpul, garis sejajar, sudut bertolak belakang, sudut sehadap, sudut dalam bersebrangan, sudut luar bersebrangan, sudut luar sepihak, dan sudut dalam sepihak.
\end{abstract}

Kata Kunci : Batik Gajah Mada Tulungagung, etnomatematika, konsep matematika

\begin{abstract}
Ethnomathematics is mathematics that found in the culture. The purpose of this research is to explore mathematical concepts in Gajah Mada Batik's Motif Sekar Jagad Tulungagung. The research method used is qualitative method with an ethnographic approach. Data collection techniques used library studies, interview, and documentation. Data analysis techniques used data reduction, data presentation, conclusion. Checking the data validity is done by extending the observation, increasing perseverance, using reference material, member check. The result of this research, in Gajah Mada batik's there are mathematical concepts in the form of two-dimensional figure, transformation geometry, angles, and line. The two-dimensional figure found in this batik is parallelogram, ellipse, rhombus. The transformation geometry that found in this batik is reflection. While the angles and line that found in this batik are obtuse, parallel line, opposite angle, upfront angle, opposite interior angle, opposite outside angle, upfront interior angle, upfront outside angle.
\end{abstract}

Keywords: Ethnomathematics, Gajah Mada batik’s Tulungagung, mathematic concept 


\section{PENDAHULUAN}

Masyarakat dan budaya merupakan sebuah satu kesatuan yang tidak dapat terpisahkan. Hal ini dikarenakan budaya merupakan suatu hal yang diciptakan dan dilakukan oleh manusia dalam kelompok masyarakatnya. Budaya merupakan suatu hal yang dekat dengan kehidupan masyarakat [1]. Budaya muncul dari kebiasaan suatu kelompok masyarakat yang dilakukan secara terus-menerus dan turun-temurun kemudian menjadi ciri khas dari suatu kelompok masyarakat tersebut. Di dalam kegiatan tersebut, terkadang terselip ilmu pengetahuan yang tidak disadari oleh masyarakat. Hal ini sejalan dengan pendapat E.B. Taylor yang mendefinisikan kebudayaan sebagai keseluruhan yang kompleks dimana di dalamnya terkandung ilmu pengetahuan serta kebiasaan yang diperoleh manusia dalam anggota masyarakat [2]. Salah satu ilmu pengetahuan yang terdapat dalam budaya yaitu matematika. Hal ini sejalan dengan pendapat Fajriyah yang menyatakan praktik budaya memungkinkan tertanamnya konsep-konsep matematika dan mengakui bahwa semua orang mengembangkan cara tertentu dalam melakukan aktivitas matematika [3].

Matematika masih dipandang sebagai suatu hal yang jauh dari kehidupan manusia. Hal tersebut dikarenakan masyarakat kurang mengetahui bahwa matematika sebenarnya sangat dekat dengan kehidupan sehari-hari mereka. Matematika merupakan suatu ilmu yang dekat dengan manusia dan digunakan dalam kehidupannya baik disadari ataupun tidak [4]. Berdasarkan penelitian Irpan menyebutkan bahwa para pedagang di Lombok Barat setiap hari menggunakan konsep matematika dalam kegiatan jual beli, konsep matematika tersebut meliputi konsep penjumlahan, pengurangan, perkalian, pembagian [5]. Maka dapat disimpulkan bahwa matematika merupakan sesuatu yang dekat dengan kehidupan masyarakat.

Ilmu yang memperlajari hubungan antara matematika dan budaya yaitu etnomatematika. Etnomatematika terdiri dari dua kata yaitu etno (etnis/budaya) dan matematika. Awalan "etno" mengacu pada budaya, "mathema" berarti menjelaskan, memahami dan pengelolaan yang berhubungan dengan aktivitas menghitung, mengukur, mengklasifikasi, pola pemodelan, sedangkan "ticks" berarti teknik [6]. Etnomatematika merupakan penelitian yang fokus terhadap hubungan antara matematika dan budaya [7]. Dari segi etimologis etnomatematika didefiniskan sebagai matematika yang dipraktekkan pada kelompok budaya yang dapat diidentifikasi seperti suku bangsa, masyarakat, dan sebagainya [8]. Etnomatematika juga didefinisikan sebagai sebuah pembangun matematika yang diikuti oleh sistem nilai, budaya dan pandangan masyarakat [9]. Secara singkat, etnomatematika memiliki pengertian matematika yang ditemukan dalam hasil praktek-praktek pada kelompok budaya tertentu.

Penelitian tentang etnomatematika khususnya tentang batik sudah banyak dilakukan sebelumnya, namun belum ada yang meneliti tentang etnomatematika Batik Gajah Mada Motif Sekar Jagad Tulungagung. Penelitian yang dilakukan oleh Zayyadi memberikan kesimpulan bahwa terdapat konsep-konsep matematika pada Batik Madura atara lain garis lurus, garis lengkung, garis sejajar, simetri, titik, sudut, persegi panjang, segitiga, lingkaran, jajar genjang, dan konsep kesebangunan [10]. Arwanto pada hasil penelitiannya memberikan kesimpulan bahwa pada Batik Trusmi Cirebon mengandung unsur-unsur matematis diantaranya adalah konsep-konsep geometri simetri, transformasi (refleksi, translasi, dan rotasi), serta kekongruenan [11]. Penelitian lain tentang etnomatematika pada batik juga pernah dilakukan oleh Ulum yang menyimpulkan bahwa pada Batik Pasedahan Suropati terdapat konsep geometri diantaranya titik, garis lurus, garis lengkung, garis zig-zag, garis tinggi, garis sejajar, sudut, segitiga, persegi panjang, oval dan simetri lipat [12].

Indonesia merupakan salah satu negara yang memiliki banyak keanekaragaman budaya termasuk di Pulau Jawa khususnya di Tulungagung. Tulungagung memiliki kebudayaan salah satunya yaitu Batik. Batik pada umumnya memiliki ciri khas tersendiri yang membedakan batik satu dengan yang lainnya. Ciri khas ini umumnya terletak pada motif dimana motif batik tersebut dibuat seperti Batik Gajah Mada Motif Sekar Jagad Tulungagung. Secara umum Batik Gajah Mada Tulungagung memiliki motif yang memuat konsep-konsep geometri. Namun belum banyak yang mengetahui bahwa terdapat konsep matematika pada Batik Gajah Mada Motif Sekar Jagad Tulungagung.

Selain sebagai informasi bagi masyarakat hasil penelitian ini juga memiliki peranan yang cukup penting dalam pembelajaran. Hasil penelitian Rosa dan Orey menyimpulkan bahwa pembelajaran dengan menggunakan sosiokultural dapat membantu siswa dalam mengembangkan intelektual, pembelajaran sosial emosional dan politik siswa dengan menggunakan acuan budaya mereka sendiri yang unik menghasilkan pengetahuan, keterampilan dan sikap yang lebih baik [13]. Selain itu penelitian lain dari Sirate memberikan kesimpulan bahwa penerapan etnomatematika dalam pembelajaran dapat memotivasi, menstimulasi, megatasi kejenuhan dan kesulitan belajar siswa dikarenakan etnomatematika sudah menjadi bagian dari keseharian siswa yang berasal dari lingkungan sosial budaya setempat [14]. Oleh sebab itu dengan 
mengetahui adanya konsep matematika khususnya geometri pada Batik Gajah Mada motif Sekar Jagad Tulungagung, maka selanjutnya hal ini dapat dimanfaatkan dalam proses pembelajaran.

\section{METODE PENELITIAN}

Penelitian ini dilakukan mulai Februari hingga April 2019. Penelitian ini dilakukan di Desa Majan, Kab. Tulungagung. Lokasi ini dipilih dikarenakan Desa Majan merupakan tempat terciptanya Batik Gajah Mada motif Sekar Jagad Tulungagung. Informan dalam penelitian ini yaitu seorang pembatik di Desa Majan, Tulungagung dan seorang budayawan yang pertama kali meneliti tentang sejarah Batik Gajah Mada Tulungagung. Jenis penelitian ini merupakan penelitian kualitatif dengan pendekatan etnografi. Pendekatan etnografi digunakan untuk mendapatkan deskripsi tentang budaya yang terdapat pada Batik Gajah Mada motif Sekar Jagad Tulungagung. Sedangkan kualitatif digunakan untuk mendeskripsikan dan menganalisis informasi secara keseluruhan. Dimana penyajian data pada penelitian kualitatif berbentuk deskriptif atau kata-kata. Teknik pengumpulan data yang dilakukan pada penelitian ini yaitu studi pustaka, wawancara dan dokumentasi. Instrumen utama dalam penelitian ini yaitu peneliti sendiri, sedangkan instrumen pendukung dalam penelitian ini yaitu pedoman wawancara. Teknik analisis data yang digunakan dalam penelitian ini yaitu reduksi data, penyajian data, kesimpulan. Pengecekan keabsahan data yang dilakukan pada penelitian ini yaitu perpanjangan pengamatan, meningkatkan ketekunan, menggunakan bahan referensi, mengadakan member check [15].

\section{HASIL DAN PEMBAHASAN}

Berdasarkan hasil wawancara dengan seorang yang pertama kali meneliti tentang Batik Gajah Mada Motif Sekar Jagad Tulungagung, motif batik ini diciptakan pertama kali pada tahun 1932. Dalam penamaannya batik ini tidak memiliki kaitan langsung dengan Patih Gajah Mada. Pencipta hanya terinspirasi dari sumpah yang diucapkan oleh patih tersebut yaitu sumpah untuk menyatukan nusantara. Oleh sebab itu batik ini memiliki ciri yaitu gabungan dari beberapa motif batik yang dijadikan satu. Selain itu ciri lain yang terdapat pada Batik Gajah Mada motif Sekar Jagad Tulungagung ini terletak pada pewarnaannya, dimana batik ini paling sedikit memiliki 5 warna yaitu biru tua, kuning, coklat, biru, dan hijau. Pemberian nama sekar jagad sendiri berasal dari kata sekar yang berarti bunga dan jagad berarti dunia, dapat diartikan menjadi bunga dunia. Oleh karena itu motif pada batik ini terinspirasi dari hal-hal di lingkungan masyarakat seperti tanaman, makanan atau benda.

Data yang diperoleh dalam penelitian ini berupa data gambar berupa foto dan data hasil wawancara peneliti dengan narasumber yang berupa transkip wawancara. Berikut merupakan gambar Batik Gajah Mada Motif Sekar Jagad Tulungagung.

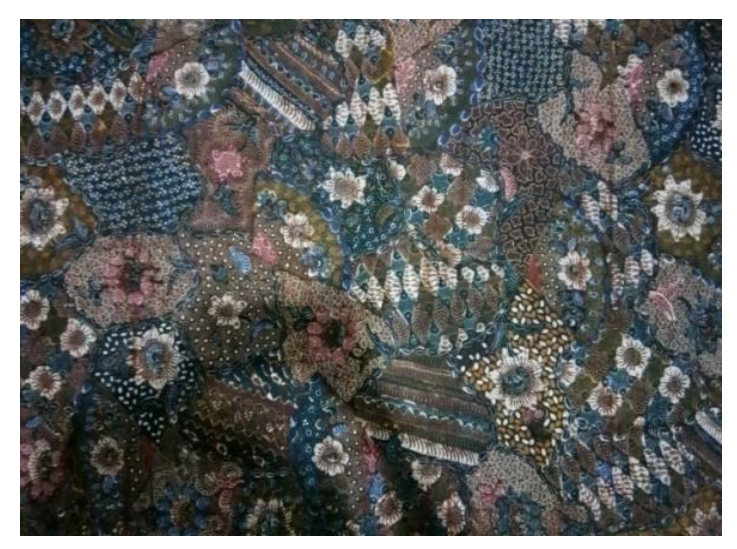

Gambar 1. Batik Gajah Mada Motif Sekar Jagad Tulungagung

Berikut merupakan penjelasan secara rinci terkait konsep matematika dan budaya yang terdapat pada Batik Gajah Mada Tulungagung: 
1.

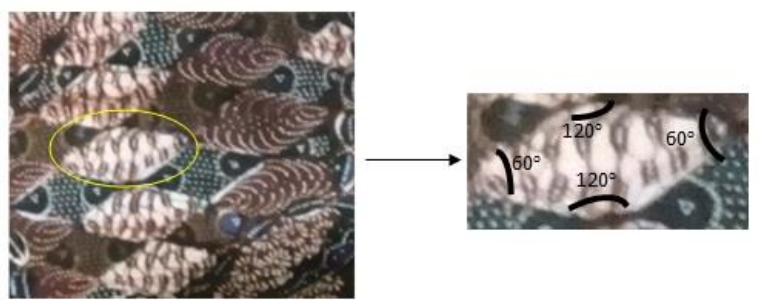

Gambar 2. Jajar Genjang

Pada Batik Gajah Mada motif Sekar Jagad Tulungagung, gambar di atas merupakan bentuk jajar genjang. Hal ini dapat terbukti dari pengukuran sudut yang dilakukan, dimana dua sisi yang saling berhadapan masing-masing membentuk sudut sebesar $60^{\circ}$ yang merupakan sudut lancip dan dua sisi lain yang saling berhadapan membentuk sudut $120^{\circ}$ yang merupakan sudut tumpul. Berikut kutipan wawancara peneliti (P) dengan narasumber $(\mathrm{N})$.

\section{P : (menunjuk pada pola batik yang dimaksud) "Kalau yang ini kenapa bentuknya seperti ini?" \\ $N$ : "Ini namanya jadah. Jadi kan jaman dulu banyak penjual jajanan di pasar, nah kemudian dari yang mereka lihat itu dijadikan ide untuk pembuatan pola batik" \\ $P$ : “Kenapa kok jadah? Kenapa bukan jajanan yang lain? \\ $N$ : "Itu karena jadah adalah salah satu jajanan yang familier dan yang mudah ditiru bentuknya. Sederhana tapi mudah diingat"}

Berdasarkan hasil wawancara tersebut, bentuk jajar genjang pada batik ini terinspirasi dari jajanan bernama jadah. Jajanan ini dipilih dikarenakan bentuknya yang mudah ditiru dan diingat oleh masyarakat. Pada pola ini juga terdapat konep matematika geometri transformasi berupa pencerminan.

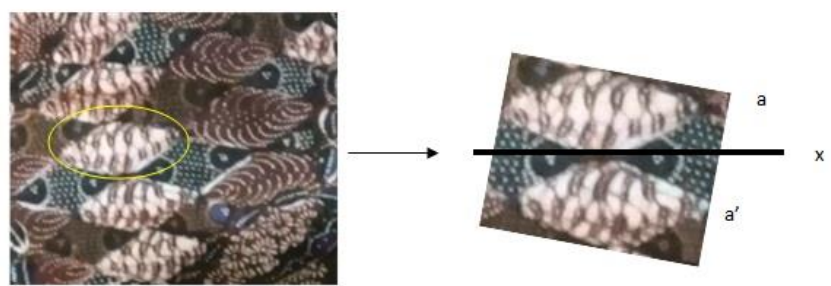

Gambar 3. Pencerminan pada Jajar Genjang

Pada gambar tersebut jajar genjang $a$ dicerminkan terhadap sumbu $x$ menjadi jajar genjang $a$ '.

2.

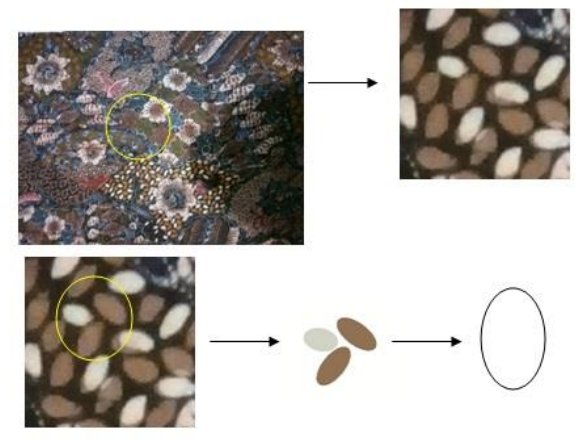

Gambar 4. Elips

Pada Batik Gajah Mada motif Sekar Jagad Tulungagung, gambar di atas merupakan bentuk elips. Hal ini dapat dilihat dari bentuk pada motif batik tersebut. Berikut kutipan wawancara peneliti $(\mathrm{P})$ dengan narasumber $(\mathrm{N})$. 

$P$ : (menunjuk pada pola batik yang dimaksud) "Kalau yang ini kenapa bentuknya seperti ini?"
$N$ : "Ini Sego ceblok/ upo ceblok. Itu idenya waktu lihat nasi sisa yang jatuh ke lantai, kan berserakan, nah kemudian dituangkan ke dalam gambar batik."

Berdasarkan hasil wawancara tersebut, bentuk elips pada batik ini bernama sego ceblok/ upo ceblok. Sego berarti nasi dan ceblok berarti jatuh. Dapat diartikan bahwa hal ini diibaratkan sebagai nasi yang terjatuh ke lantai.

3.

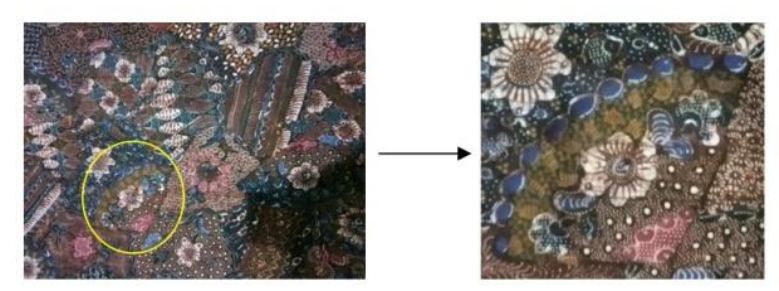

Gambar 5. Kipas dan Rantai

Jika diamati terdapat bentuk kipas dan rantai pada motif batik ini. Menurut Bapak Alex selaku pembatik, kipas bermakna sayonara atau perpisahan sedangkan rantai diibaratkan sebagai lambang persatuan atau mempererat. Hal ini bermakna seberapa jauhpun terpisah, silahturahmi dapat tetap terjalin dengan baik. Pada pola ini terdapat isian berupa bunga dan titik-titik besar yang memiliki makna tersendiri.

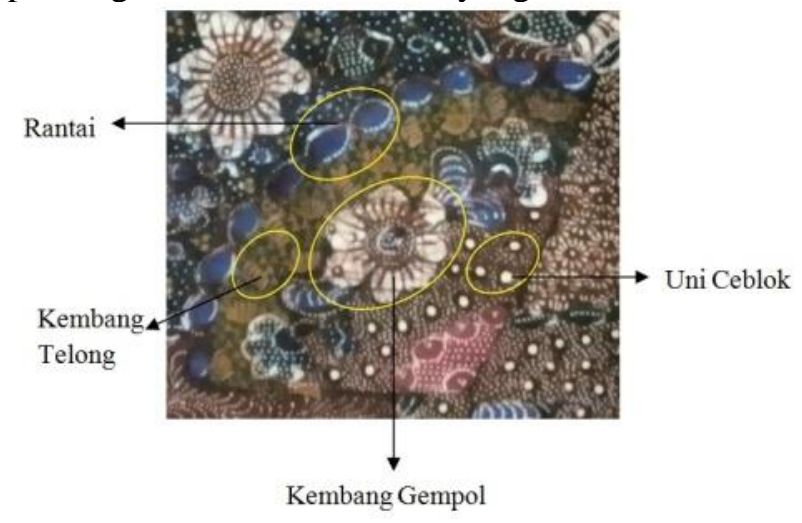

Gambar 6. Detail Kipas dan Rantai

Terdapat gambar bunga pada isian kipas tersebut yang bernama bunga gempol atau kembang gempol. Alasan penggunaan bunga ini karena masyarakat sering menemui bunga ini di depan rumah. Pada bagian bawah terdapat titik-titik yang berukuran lebih besar daripada titik yang di sekitarnya, titik itu bernama uni ceblok yang berarti isi mauni yang terjatuh. Pada jaman dahulu di sekitar sungai banyak ditemukan pohon mauni, di bawahnya biasanya terdapat biji dari pohon mauni yang berjatuhan. Sedangkan pada bagian atas bunga terdapat garis-garis kecil yang berwarna kuning, ini dinamakan kembang telong. Berikut kutipan wawancara peneliti $(\mathrm{P})$ dengan narasumber $(\mathrm{N})$.

$$
\begin{aligned}
& P \text { : "Pak, kalau dilihat detail, apakah benar ada gambar kipas pada batik ini?" } \\
& N \text { : "Iya benar, ini kan kipasnya (menunjuk ke gambar kipas) dan di tepinya ini rantai, yang }
\end{aligned}
$$


$N$ : "Iya benar, itu kembang gempol, bunga gempol. Dulu itu banyak sekali disini tapi sekarang sudah tidak ada. Kalau yang kuning-kuning ini (menunjuk gambar) ini kembang telong kalau titik-titik besar bawah ini uni ceblok, itulo isi mauni seng ceblok. Ceblok itu jatuh. Dulu di sekitar sungai sini, pinggiran sungai ini banyak pohon mauni kan, jejer-jejer nah itu biasanya bijinya jatuh di bawahnya itu. Trus masyarakat terinsipirasi mengambarnya di motif batik. Jadi jaman dulu itu mereka lihat apa, menemui apa itu bisa dijadikan inspirasi membatik. Makanya membatik itu sebenarnya bisa dilakukan kapan saja. Se munculnya ide. Gitu saja. Pokok tau apa gitu digambar."

$P$ : “Untuk pemilihan bunga, kenapa kok bunga gempol yang dipilih, kenapa bukan yang lain?"

$N$ : "Nggak ada alasan khusus mbak, karena ya itu tadi, mereka sering lihat itu di depan rumah mereka, trus digambar gitu saja."

$P$ : "Untuk jumlah kelopak bunga, apakah ada jumlah tertentu."

$N$ : "Nggak, itu hanya kreasi saja. Tidak ada jumlah khusus."

$P$ : "Untukjumlah uni ceblok juga, apakah ada jumlah tertentu yang melambangkan sesuatu?"

$N$ : “Tidak. Itu hanya variasi saja, digunakan sebagai isian."

Konsep matematika yang terdapat pada pola ini yaitu bangun datar berupa elips, geometri transformasi berupa pencerminan, dan sudut.

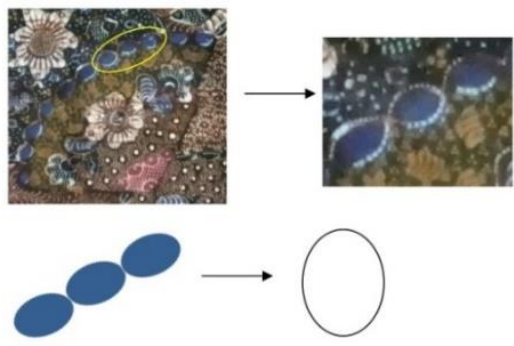

Gambar 7. Bangun Datar Elips pada Rantai

Pada pola tersebut, rantai memiliki pola dasar berupa elips. Hal tersebut dapat dilihat pada Gambar 7.

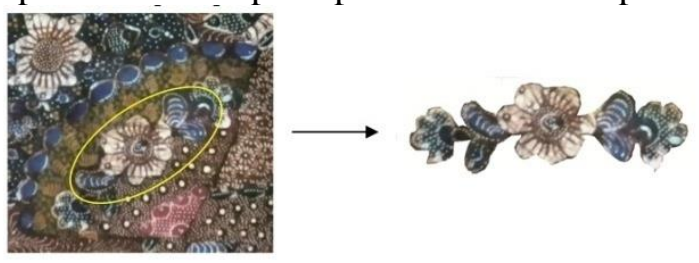

Gambar 8. Kembang Gempol

Pada Gambar 8 kembang gempol tersebut terdapat konsep matematika geometri transformasi berupa pencerminan, hal tersebut dapat dilihat pada Gambar 9.

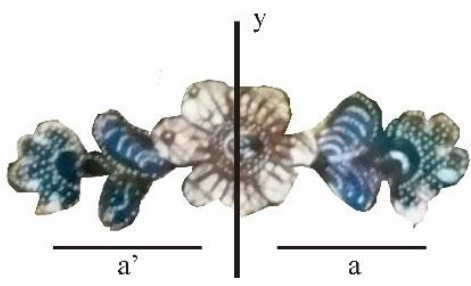

\section{Gambar 9. Pencerminan pada Kembang Gempol}

Pada bagian $a$ dicerminkan terhadap sumbu y akan menghasilkan a'. Sedangkan konsep sudut dapat ditemukan pada bentuk kipas. 


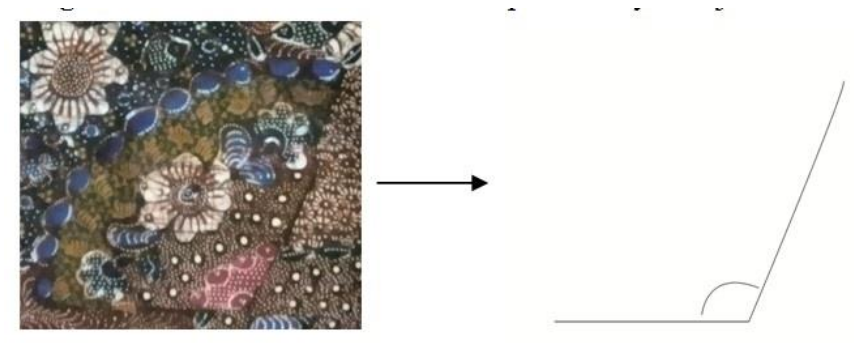

Gambar 10. Sudut pada Kipas

Dari Gambar 10 dapat dilihat bahwa pada ujung kipas membentuk sebuah sudut. Adapun sudut yang terbentuk sebesar $110^{\circ}$, jadi ini merupakan sudut tumpul.

4.

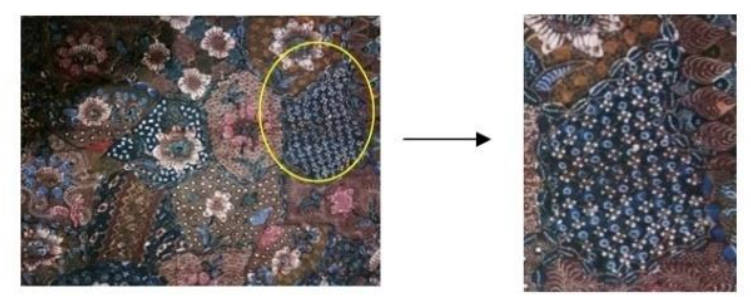

Gambar 11. Gambiran

Pada Gambar 11 tersebut bernama gambiran. Menurut Bapak Alex selaku pembatik, gambiran merupakan salah satu hal yang digunakan untuk nginang. Pada jaman dahulu masyarakat memang banyak yang memiliki kebiasaan nginang. Nginang pada jaman dahulu dipercaya masyarakat dapat membuat gigi menjadi lebih kuat. Berikut kutipan wawancara peneliti $(\mathrm{P})$ dengan narasumber $(\mathrm{N})$.

$P$ : "Kalau yang ini namanya apa pak (menunjuk gambar)?"

$N$ : "Itu gambiran. Gambir itu kan bahan buat nginang. Itu lo, yang bentuk e kayak batu kecil, jika orang dulu makan sirih dicampur itu. Lha biasanya wadah e kotak kecil-kecil gitu, akhirnya dibuat kreasi seni, dituangkan ke dalam bentuk gambar di batik."

$P$ : "Alasannya dipilih apa pak?"

$N$ : "Kenapa di pilih, karena orang jaman dulu konon tiap hari merawat gigi dengan itu, biar kuat. Mitos e juga kalau makan itu bisa awet muda. Pokok orang jaman dulu kalau makan sirih, giginya jadi ada merah-merahnya gitu lo mbak."

Pada pola ini terdapat konsep matematika bangun datar berupa belah ketupat transformasi geometri berupa pencerminan, sudut, dan garis sejajar.
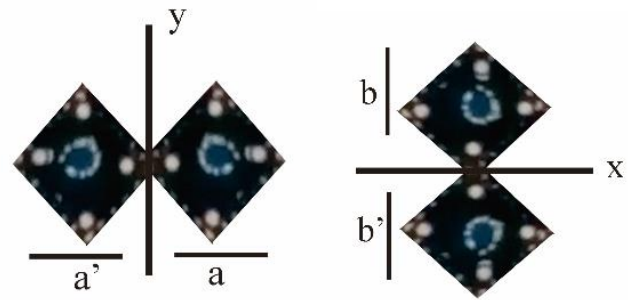

Gambar 12. Pencerminan pada gambiran

Pada Gambar 12 dapat dilihat bahwa terdapat belah ketupat a dicerminkan terhadap sumbu y menghasilkan belah ketupat a'. Sedangkan belah ketupat b dicerminkan terhadap sumbu x menjadi belah ketupat b'.

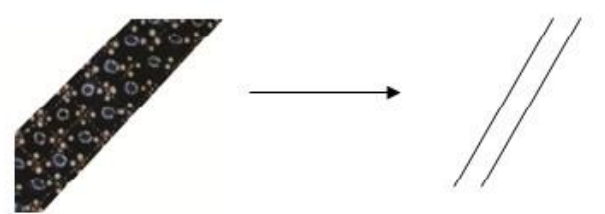

Gambar 13. Garis Sejajar pada Gambiran 
Garis tepi pada pola ini jika diamati maka membentuk garis sejajar seperti yang dapat dilihat pada Gambar 13.
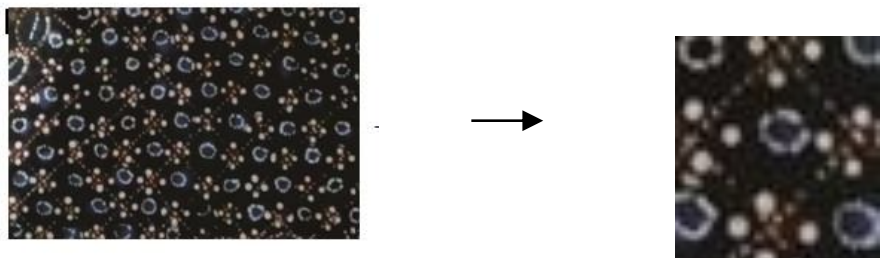

Gambar 14. Belah ketupat pada Gambiran

Pada Gambar 14 dapat dilihat bahwa motif ini membentuk sebuah bangun berupa belah ketupat. Hal ini dapat dilihat dari empat rusuk yang sama panjang.

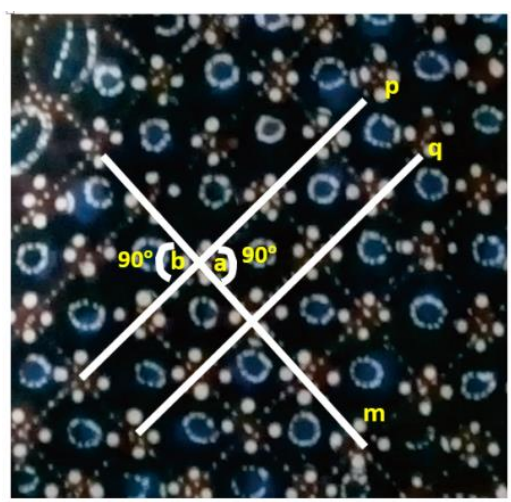

\section{Gambar 15. Sudut Bertolak Belakang pada Gambiran}

Gambar 15 menunjukkan terdapat sudut bertolak belakang pada gambiran. Adapun sudut yang terbentuk yaitu sebesar $90^{\circ}$, sudut dibelakangnya pun juga sebesar $90^{\circ}$ dimana hal ini sesuai dengan sifat sudut bertolak belakang dimana setiap pasang sudut yang saling bertolak belakang akan memiliki ukuran sudut yang sama.

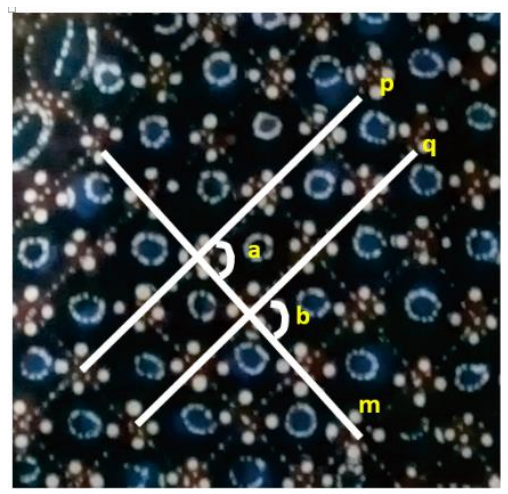

\section{Gambar 16. Sudut Sehadap pada Gambiran}

Gambar 16 menunjukkan terdapat sudut sehadap pada gambiran. Pada gambar tersebut garis $\mathrm{p} / / \mathrm{q}$ dipotong oleh garis $\mathrm{m}$. Sudut a dan sudut $\mathrm{b}$ berada di atas garis $\mathrm{m}$ dan masing-masing berada di sebelah kanan garis sejajar yaitu garis $\mathrm{p}$ dan $\mathrm{q}$. 


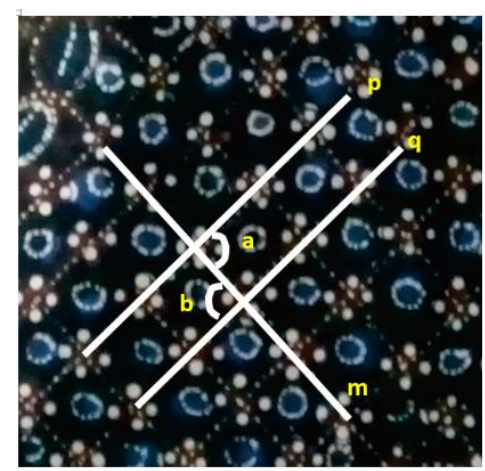

\section{Gambar 17. Sudut Dalam Bersebrangan pada Gambiran}

Pada Gambar 17 garis yang terdapat pada gambiran dapat membentuk sudut dalam bersebrangan. Dimana sudut sudut yang berada di dalam (di antara) dua garis sejajar dan letaknya saling bersebrangan. Pada gambar tersebut garis $\mathrm{p} / / \mathrm{q}$ dipotong garis $\mathrm{m}$. Sudut a dan sudut $\mathrm{b}$ saling bersebrangan dan berada di dalam garis $q$ dan $r$.

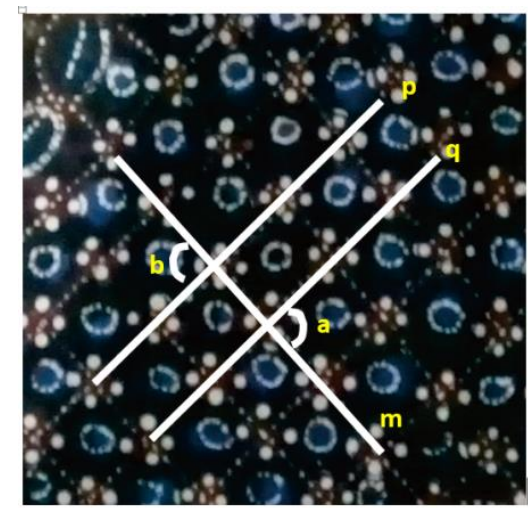

\section{Gambar 18. Sudut Luar Bersebrangan pada Gambiran}

Pada Gambar 18 garis yang terdapat pada gambiran dapat membentuk sudut luar bersebrangan. Pada gambar tersebut garis $\mathrm{p} / / \mathrm{q}$ dipotong oleh garis $\mathrm{m}$. Sudut a berada di sebelah kiri garis q (di sisi luar). Sedangkan sudut $\mathrm{b}$ berada di sebelah kanan garis $\mathrm{p}$ (di sisi luar). Maka sudut a dan b membentuk sudut luar bersebrangan.

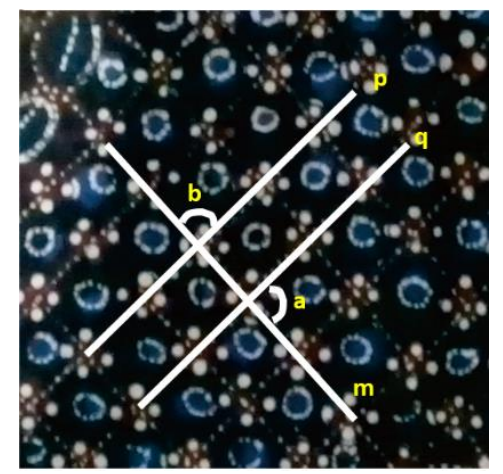

Gambar 19. Sudut Luar Sepihak pada Gambiran

Pada Gambar 19 garis yang terdapat pada gambiran dapat membentuk sudut luar sepihak. Pada gambar tersebut garis $\mathrm{p} / / \mathrm{r}$ dipotong garis $\mathrm{m}$. Sudut a berada di sebelah kanan garis $\mathrm{q}$ (di sisi luar). Sedangkan sudut $\mathrm{b}$ berada di sebelah kiri garis $\mathrm{p}$ (di sisi luar). Sehingga sudut a dan sudut b membentuk sudut luar sepihak. 


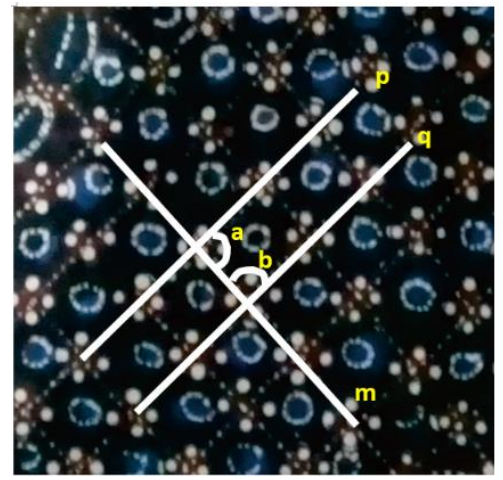

Gambar 20. Sudut Dalam Sepihak pada Gambiran

Pada Gambar 20 garis yang terdapat pada gambiran dapat membentuk sudut dalam sepihak. Pada gambar tersebut garis $\mathrm{p} / / \mathrm{r}$ dipotong garis $\mathrm{m}$. Sudut a berada di sebelah kanan garis $\mathrm{p}$ (di sisi dalam). Sedangkan sudut b berada di sebelah kiri garis q (di sisi dalam). Sehingga sudut a dan sudut b membentuk sudut dalam sepihak.

Berdasarkan hasil pembahasan diatas menunjukkan bahwa terdapat konsep matematika pada Batik Gajah Mada motif Sekar Jagad Tulungagung. Konsep geometri yang terdapat pada Batik Gajah Mada motif Sekar Jagad Tulungagung yakni konsep bangun datar, geometri transformasi, sudut dan garis. Geometri bangun datar yang terdapat pada batik ini berupa jajar genjang, elips dan belah ketupat. Hal ini sejalan dengan hasil penelitian Zayyadi yang menyimpulkan bahwa terdapat konsep matematika berupa jajar genjang pada Batik Madura [10]. Bangun datar elips juga terdapat pada motif Batik Kawung Yogyakarta seperti pada kesimpulan penelitian Pradanti [16]. Sedangkan bentuk belah ketupat sejalan dengan hasil penelitian Sudirman yang menyimpulkan bahwa terdapat bentuk jajar genjang pada motif Batik Paoman [17].

Konsep geometri transformasi yang terdapat pada Batik Gajah Mada Tulungagung berupa pencerminan. Hal ini sejalan dengan hasil penelitian Fadila yang menyimpulkan bahwa terdapat ilmu geometri transformasi berupa pencerminan pada motif Batik Lampung. Konsep sudut dan garis pada Batik Gajah Mada motif Sekar Jagad yakni sudut tumpul, garis sejajar, sudut bertolak belakang, sudut sehadap, sudut dalam bersebrangan, sudut luar bersebrangan, sudut luar sepihak, sudut dalam sepihak. Hal tersebut sejalan dengan hasil penelitian Zayyadi yang menyimpulkan bahwa terdapat garis sejajar dan sudut pada motif Batik Madura [10]. Hasil penelitian Ulum juga menyimpulkan bahwa terdapat konsep matematika berupa sudut pada motif Batik Pasedahan Suropati [12].

\section{KESIMPULAN}

Berdasarkan hasil penelitian tersebut dapat disimpulkan bahwa pada Batik Gajah Mada motif Sekar Jagad Tulungagung terdapat konsep matematika khususnya konsep geometri. Konsep geometri yang terdapat pada Batik Gajah Mada motif Sekar Jagad berupa bangun datar, geometri transformasi, sudut dan garis. Adapun bangun datar yang terdapat pada batik ini yaitu jajar genjang, elips dan belah ketupat. Geometri transformasi yang ditemukan pada batik ini yaitu pencerminan. Sedangkan sudut dan garis yang ditemukan pada batik ini berupa sudut tumpul, garis sejajar, sudut bertolak belakang, sudut sehadap, sudut dalam bersebrangan, sudut luar bersebrangan, sudut luar sepihak, sudut dalam sepihak.

\section{DAFTAR PUSTAKA}

[1] J. Afandi, "Pengembangan Perangkat Pembelajaran Matematika dengan Pendekatan Kontekstual Budaya Lombok," Beta (Jurna Tadris Mat., vol. 10, no. 1, pp. 1-17, 2017.

[2] Inrevolzon, "Kebudayaan dan Peradaban," J. Sej. dan Kebud. Islam Fak. Adab dan Hum. IAIN Raden Fatah Palembang, 2013.

[3] E. Fajriyah, "Peran Etnomatematika Terkait Konsep Matematika dalam Mendukung Literasi," Prism. Pros. Semin. Nas. Mat., vol. 1, no. 1, pp. 112-119, 2018.

[4] P. Wijayanti, "Matematika Dalam Kegiatan Sehari-Hari Masyarakat," Pros. Semin. Nas. Penelitian, Pendidik. dan Penerapan MIPA, pp. 497-500, 2009. 
[5] S. Irpan, "Praktek Konsep-Konsep Matematika Dasar dalam Kegiatan Jual Beli di Pasar Gunungsari Lombok Barat," Beta (Jurna Tadris Mat., vol. 8, no. 2, pp. 193-222, 2015.

[6] P. Sopamena and F. Juhaevah, "Karakteristik Etnomatematika Suku Nuaulu di Maluku Pada Simbol Adat Cakalele," Barekeng J. Ilmu Mat. dan Terap., vol. 13, no. 2, pp. 75-84, 2019.

[7] F. J. Albanese, Veonica; Perales, "Enculturation with Ethnomathematical Microprojects: From Culture to Mathematics," J. Math. Cult., vol. 9, no. 1, pp. 1-11, 2015.

[8] U. D. Ambrosio, "Ethnomathematics and its Place in the History and Pedagogy of Mathematics.," Learn. Math. - An Int. J. Math. Educ., vol. 5, no. 1, pp. 44-48, 1985.

[9] R. Sulaiman, A. H. Husain, and R. Sulaiman, “Appreciation of Siri Dungun Paintings in Ethnomathematics Context,” Int. J. Acad. Res. Bus. Soc. Sci., vol. 9, no. 9, pp. 1116-1126, 2019, doi: 10.6007/IJARBSS/v9i9/6406.

[10] M. Zayyadi, “Eksplorasi Etnomatematika Pada Batik Madura,” EIgma, vol. 2, no. 2, pp. 35-40, 2017.

[11] Arwanto, "Eksplorasi etnomatematika batik trusmi cirebon untuk mengungkap nilai filosofi dan konsep matematis," Phenom. J. Pendidik. MIPA, vol. 7, no. 1, pp. 40-49, 2017.

[12] B. Ulum, M. T. Budiarto, and R. Ekawati, "Etnomatematika Pasuruan : Eksplorasi Geometri Untuk Sekolah Dasar Pada Motif Batik Pasedahan Suropati," Pros. SI MaNIs (Seminar Nas. Integr. Mat. dan Nilai Islam., vol. 1, no. 1, pp. 70-78, 2017.

[13] M. Rosa and D. C. Orey, "Ethnomathematics : aspek budaya matematika Etnomatemática : os aspectos culturais da Matematica," Rev. Latinoam. Etnoatematica, vol. 4, no. 2, pp. 32-54, 2011.

[14] F. S. Sirate, "Implementasi Etnomatematika Dalam Pembelajaran Matematika Pada Jenjang Pendidikan Sekolah Dasar," Lentera Pendidik. J. Ilmu Tarb. dan Kegur., vol. 15, no. 1, pp. 41-54, 2012, doi: 10.24252/lp.2012v15n1a4.

[15] Sugiyono, Metode Penelitian Pendidikan Pendekatan Kuantitatif, Kualitatif dan R\&D. Bandung: Alfabeta, 2008.

[16] P. Pradanti, “Geometri Transformasi dalam Motif Batik Kawung Yogyakarta,” Pros. Semin. Nas. Mat. dan Ter., pp. 357-370, 2016.

[17] Sudirman, A. L. Son, and Rosyadi, "Penggunaan Etnomatematika Pada Batik Paoman Dalam Pembelajaran," Indomath Indones. Math. Educ., vol. 1, no. 1, pp. 27-34, 2018. 
